\title{
MEMORIES FROM THE FUTURE: CONSTATIVE AND PERFORMED IDENTITIES IN IDEOLOGIZED SPACES
}

\author{
Felix NICOLAU \\ University of Lund \\ Technical University of Civil Engineering of Bucharest \\ e-mail: felix.nicolau@ rom.lu.se
}

\begin{abstract}
Although communism was a Western creation, its last consequences were implemented in southeastern Europe. In addition to the imposed aspects, there were local enthusiasms and excesses of zeal (euphemistically speaking), which attest to the existence of an identity matrix and a common mentality. Countries with an authoritarian tradition have absorbed this ideology of simultaneous denationalization and supra-nationalization to the deepest. In addition, after the fall of the Iron Curtain in 1989, the Southeast European space preserved mass nostalgia: Stalin, Tito and Ceausescu are still guardianship figures for many of various social categories. Imperialist stability and/or glory are two of the most important reasons for forgetting communist terror. The research tries to identify and analyze the sources of historical instability that has an impact on the postcommunist present - the communist heritage still looming large-, as well as to demystify certain stigmas unconditionally applied to Southeast European civilizations: corruption, laziness, negative Balkanization, frivolity and lack of consistency. This selective overview aims to decant common mentalities of synchrony in relation to diachrony.
\end{abstract}

Keywords: Southeast Europe; communism; post-communism; corruption; authoritarianism; totalitarianism.

„Marele pericol pe care-1 reprezintă sistemul de securitate al statului totalitar este că marea putere de care beneficiază instituția o poate pune în situația de a lua decizii fundamentale pentru stat, cu implicații în evoluția acestuia pe o perioadă de timp chiar foarte lungă" (Flori Bălănescu în dialog cu Cristian Troncotă, Securitatea noastră cea de toate zilele, 2020: 18) ${ }^{3}$.

\footnotetext{
${ }^{3}$ Flori Bălănescu, "The great danger represented by the Securitate system of a totalitarian state is that the immense power held by the institution could place it in a position wherefrom it can make crucial decisions for the state, with long-lasting implications in the state evolution" (translation mine) (Flori Bălănescu în dialog cu Cristian Troncotă, Securitatea noastră cea de toate zilele/ Flori Bălănescu's dialogue with Cristian Troncotă. Our Daily Securitate, Bucureşti, Corint Press, 2020).
} 


\section{Purpose and scope}

The purpose of my article is to identify some of the traits that are responsible for the preservation of communist approach in South-Eastern Europe after 1989, but also the discourse engulfing it. Because there is no doubt whatsoever that communist mentalities persisted at all social levels (coteries, nepotism, blasphemy, supervision, substantial funds dedicated to special services and so on, the continuity in politics and in state structures of secret services). For instance, in Romania of the last ten years there were disclosures in media about the collaboration with Securitate of well-known intellectuals, of an ex-president of the country after the fall of communism, of politicians and superior magistrates (all can be easily identified at a routine search on Google), or about officers in the refurbished secret services working undercover as journalists, or about subterranean protocols signed between state structures that should have observed the principle of separation of powers, not to say more.

I shall proceed with a few generalizing considerations on the communist doctrine and then I shall cross-examine the present day political and economic situation in a few ex-communist states. The haunting question is whether a new empire at the horizon could show up a little too early for the peoples who had come out of communism with a confused identity and an empty stomach.

\section{The itchy matter of sovereignty. Empires and utopias}

The Communist Manifesto, devised in 1847 and published in 1848, had two earlier versions written by Friedrich Engels: "Communist Confession of Faith" and "The Principles of Communism". Marx was the one who asked for the sinking of terms of religious connotation (like "faith" and "catechism") in favour of the lay term "Manifesto" (Marx, 1987: 3). However, the imprint of religion or of romantic genius persisted, as in the Preface to the 1893 Italian edition, where Engels "perorated": "Will Italy give us the new Dante, who will mark the hour of our birth of this new proletarian era?" (Marx, 1987: 13.). It was obvious from the beginning that the Manifesto stressed the persuasive and charismatic elocutions, not the rational and scientific side.

In practice, communism showed a surprising unity in ferocity across the globe. It looks as if every type of utopia is doomed to end in totalitarianism. However, totalitarian atrocities are doomed in their turn. Nevertheless, the paranoia of communist regimes and its fateful consequences proved to be slow and painful. An abrupt change, definitively 
detached from this past, would have been another utopia: "In un regime che annienta gli oppositori, solo il partito al potere può generare, infatti, i riformatori del sistema stesso" (Perrini, 1992: 1) ${ }^{4}$.

The communists came much faster into power then they got dispossessed of it. The disenfranchisement came in instalments. There were successive perestroika-s like that initiated by Imre Nagy in Budapest in 1956, but all of them were brutally stifled. The perverse nature of the implemented communism was so morphotic that Nikita Khrushchev could vent out his report on Stalin's crimes in 1956, while in the same year the Soviets crushed the Hungarian revolt. Even 30 years after the fall of the Soviets we could recognize some of the geo-political ideas promoted during "Brezhnev's doctrine" as the limited sovereignty of the communist European countries (at that time a step forward to relaxation). Nowadays, we may see that the concept of sovereignty is again at stake.

Thirty years after the fall of the Iron Curtain, a renewed hate against Christianity is perceived in the former communist countries, in the sequel of previous communist persecutions against churches and priests. Even the Italian Catholics admit the importance of the resistance put to the communist barbarity by the Orthodox Russian Church: "La Chiesa ortodossa in Russia, qualiche siano stati gli inevitabili cedimenti della gerarchia a un'oppressione totalitaria mai vista prima nella storia, è una Chiesa martire che ha percorso la sua Via Crucis fino in fondo" (Perrini, 1992: 2) .

After so many sacrifices, it is normal for the smaller states transformed by the Soviets into vassals to crave for sovereignty, not for sudden absorption into other empires. "Ma una volta riconquistata l'indipendenza il primo obiettivo dei nuovi Stati non dovrebbe essere propprio quello di entrare questa volta liberamente, a far parte di una communità sovranazionale" (Perrini, 1992: 3$)^{6}$ - remarks the Italian journalist.

Indeed, the Soviet Empire fell to pieces miraculously without enormous bloodshed. Nevertheless, the happy-end of an atrocious experiment should not tranquilize the public conscience. Perrini expressed such a worry: "Un progetto multinazionale oggi per esistere ha bisogno d'una democrazia

\footnotetext{
4 "In a regime which annihilates opponents only the party in power can generate, indeed, the reformers of the system itself".

5 "The Orthodox Church in Russia, irrespective of the inevitable giving in of the hierarchy to a totalitarian oppression of a kind first encountered in history, is a martyrized Church that perambulated its Via Crucis right to the end".

6 "But once the independence regained, the first objective of the new States shouldn't be exactly to enter, this time free willing, an over-national community".
} 
che rispetti i diritti delle singole nazionalità e al loro interno garantisce $\mathrm{i}$ diritti delle minoranze" (Perrini, 1992: 2) ${ }^{7}$.

Is it not the temptation to encourage another empire, with its specific set of ideologies, another incumbent utopia? That is why the journalist speaks of the Pilateism of the West ("il pillatismo dell' Occidente") (Perrini, 1992: 5).

\section{Re-writing the most atrocious communist experiment}

In 2019, some members of the new-fangled Romanian Communist Party gathered in front of the ill-famed communist prison in Piteşti and displayed communist symbols. They declared that what happened to the abused students some seventy years ago was a stupendous and well-deserved treatment because they were anti-communists and fascists. Two middle-aged researchers, Mihai Demetriade şi Mădălin Hodor, working at Consiliul Naţional pentru Studierea Arhivelor Securităţii - CNSAS (The National Council for the Study of the Securitate Archives) found excuses for the horrendous display coming from the new communist party. They reiterated the perverse arguments used by Securitate after 1952, namely that the most ferocious communist penitentiary experiment was implemented by the legionaries (former nationalist-orthodox party) without the knowledge of the authorities. The prisoners would have bestially tortured one another out of...fun in the most horrendous communist penitentiary experiment "staged" in a prison located in Piteşti. Virgil Ierunca, a famous journalist at Radio Free Europe, wrote a book, Fenomenul Piteşti (The Piteşti Phenomenon), wherein he described the atrocities committed there. He remarked that nowhere in the communist camp the political detainees were forced systematically and brutally to become the torturers of their own friends and relatives. All of a sudden, this foundational book is forgotten, together with so many others which described the terror of totalitarianism. Precisely the researchers paid to study this shameful episode in the $20^{\text {th }}$ century managed to uncover unexpected and whitewashing perspectives. Communist totalitarianism emerges unpredictably as a fairy tale (see links at References).

\section{Linguistics of dissimulation: constative and performative utterances}

Communism in its Marxian clothes has always fared well in Europe and for a while now it has crossed the Ocean. Peter Sloterdjik argued in Critique of Cynical Reason that this is explainable not through Marx's postulate of "false consciousness" ("they do not know it but they are doing it"), but through an "enlightened false consciousness" ("they know very well what they are doing, but still, they are doing it" (Sloterdjik in Yurchak, 2005:

\footnotetext{
7 "A multinational project in order to exist today necessitates a democracy able to respect the rights of every nation and within their frame to warrant the rights of minorities".
} 
7). This is another facet of performativity: not engendered by oppression, but playing the role of conscience-blanket. If "many Western subjects are postmodern cynics who insist on wearing a mask of misrecognition" (Yurchak, 2005: 12) because they became addicted to consumerism, they became also bipolar, sheltering inside a "gap...between performance and belief" (Wedeen, 1999: 78). The profile of a pink communism is getting visible, with a new kind of social performativity. Communication and spiritual construction are mimicked while the focus point is far away from these.

In 1979, Václav Havel wrote the essay "The Power of the Powerless" (published in 1986). In it, he advanced the idea that the citizens of socialist Czechoslovakia resorted to ideological lies in order to avoid problems with the regime (Havel in Yurchak, 2005: 12). The same dissimulating conformism was identified by Oleg Kharkhordin in the Russian society, with the hide-and-seek between the "official public" and the "hidden intimate" (Kharkhordin in Yurchak: 12). This is the area of performativeness that invokes the situatedness of communication (Voloshinov, 1986: 86). Even Mikhail Bakhtin highlighted the importance of the agentive processes. The productive and dialogic understanding of language described the speaking self as a "voice" always "dialogized", never static, open to reciprocal and multiple reflection of "voices", down to hyperglossia.

John Austin took further Bakhtin's theories on the productive nature of language. In his speech act theory, he contrasted "constative" utterances (stating facts) with "performative utterances" or "performatives" (changing realities instead of describing them). Because they transmit meaning, constative utterances move between binary borders: true or false. Performative utterances convey energy and influence, so they can be felicitous or infelicitous, adapted or non-adapted.

Austin underlined that the performativeness of an utterance cannot be wholly determined by the speaker's intention. A great share of this is generated by "the accepted" conventions surrounding the utterance "with the purpose of obtaining suitable conventional results" (Austin in Yurchak, 2005: 14). Jacques Derrida completely did away with the speaker by stating that a performative utterance is made successful by the concentration of speech acts and not by a personal intention. It would exist a conventionality of a speech act in relation to an assumed "coded" or an "iterable" model. In this way, the speech act acquires the functionality of a citation to be reused in a number of contexts only apparently distinct (Derrida, 1977: 191-92). Thus, the speech act remains always undetermined because of its citationality and of the indeterminacy of the context. "This ability of the speech act to break with the context is a constitutive element of its performative force", argued Derrida (Derrida, 1977: 15). Allegedly, only courageous speech acts manage to defy 
the sway of context. However, Derrida focused only on the semiotic level of discourse while the external social conventions implying a complex interplay of force institutions in a totalitarian state dimmed away. Citizens socially performed as actors in a rigid and propagandistic play. Performativeness was both ambiguous and psychologically and intellectually maiming. The crash of communist austerity was often replaced by a financial austerity in combination with a flood of material products. It is not the offer that topped the demand; actually, the annihilation of the productive structures frustrated a demand that became hysterical after so many years of scarcity. The generosity of the offer presented itself as bait for many impoverished and underpaid citizens.

\section{Could wild neoliberalism re-enfranchise communism in the Balkans and around?}

All former communist countries in the South-Eastern Europe lived the process of McDonaldization as it was described by George Ritzer (The McDonaldization Thesis, Sage Publications, London, New York, 1998). This implied also an almost unlimited deregulation of markets and the cancellation of the social welfare system.

This is perfectly true of Romania, for instance, where almost all stateowned lodgings, rented out at convenient prices, were sold for below-market prices to individuals with easier access to the Establishment. The wild neoliberalism is detectable in the proliferation of "McJobs" which are insecure, low-paid jobs, and are a twisted stimulus to mass-migration.

The state in former communist countries was weakened as in some Middle Orient and North African areas where citizens, frustrated with communist greyish towns/cities, were induced a "soporific consumption" (Abaza, 2006: 25). The new slogan, that was supposed to cover the slithering in of the new ideologies, was "Consume but shut up!" (Abaza, 2006: 25). Nevertheless, large wedges of population could afford to consume only counterfeited merchandise.

In Balkan countries, malls are placed in (semi)central position in many cities, whereas in Central, Northern, and Western Europe they are displaced to the outskirts or even to a few bus stops' distance from the centre. H. G. Wells postulated that post-urban city would be essentially a bazaar, "a great valley of shops" (Wells in Abaza, 2006: 29). These consumerist venues contributed to the fake occidental hype and made many citizens blind to the permanence of old habits: corruption, low wages, mafia clans, social insecurity, sub-financed educational systems, fraudulent large businesses, and the spoiling of raw materials by multinational corporations, brain drain, key positions in the state structures and in important companies dedicated to secret service agents, the snubbing of the principle of separated powers in the 
state, undercover secret services agents implanted in mass media and so on and so forth.

The former communist countries were also - even if much later - coopted in "the constitution of the narcissistic society of modernity" (Abercrombie\&Longhurst, 1998: 2). What for the Western Europe had constituted the frame of modernity, for the South-Eastern Europe was the retrieval of a belated modernity. "In their case, media works also as a narcotic where messages are injected into the mass audience as if from a hypodermic syringe" (Abercrombie\&Longhurst, 1998: 5). This external synchronicity put to slumbers the civic and political conscience of many citizens in this part of Europe. The newly found postmodernity generated a sense of exhilaration. The masses got entrapped into "the circle of ideology" (Abercrombie\&Longhurst, 1998: 12). Thus, many people hated communism but still attended to its values because of a forged, star-spangled reality: "If the media were involved in constructing consent, they could no longer be seen as reflecting reality" (Abercrombie\&Longhurst, 1998: 11).

In Steven Sampson's view, there is a benevolent colonialism in the Balkans which surfaces under the guise of allegedly western-validated forms of democracy: "Cloning of NGO's is a typical exit strategy in many former East-European countries" (Sampson in Sanimir \&Tornquist-Plewa, 2002: 38). It would be hard to contradict him once we learn that only in Romania there are around 90,000 NGOs, many of these benefiting of foggy subsidies. When some governments asked for a regulation and clarification of sponsorship in the case of NGOs, there followed scandals and public protests. The accusation was that politicians tried to hedge democracy. NGO's representatives always claimed they act on behalf of civil society, without promoting a hidden political agenda.

\section{Russia remote past $\&$ past}

The question is whether Russia and its satellites were prone to communist excesses because of their past and whether they could be more fragile in terms of democratic fulfilment when exposed to financial and ideological pressure.

So often, there was invoked in the case of Russia the peculiar sociopolitical pattern that prompted the upheaval of communism: "Russia provided no passive, insulated social laboratory within which the dreams of Europe's socialist tradition could be put to scientific test; to its last day, every aspect of Soviet socialism reflected the legacy of Imperial Russia" (Acton, 1986: XIII). The quandary is how socialism radicalized itself into brutal communism in Russia then spread its tentacles across a huge lapse of Asian and European territory. 
The Mongol stamp on this scar of Russian history is not precisely perceivable because Mongols' dominance was overthrown in 1480. Before that date, they confined their actions to plundering, to collect tribute and occasionally military recruits: "Their rule was indirect and their interference in native custom and traditions relatively superficial" (Acton, 1986: 10).

However, there are some discernible differences in the administrative system between Russia and the Western countries. Among these: primogeniture was not implemented in Russia, the parental property being partitioned among the heirs; senior positions in the royal service were not accessed through competition, but as the result of the best integration into the mestnichestvo (boyar ranking) system; enslavement became overwhelming and lands were distributed conditionally (pomestie), in exchange for annual military service, thus being shaped the class of service landowners (pomeschiki) (Acton, 1986: 20-23). Basically, every form of major compensation derived from the tsar's superpowers.

In the same line of arbitrary decision is to be mentioned the death squad created by Ivan the Terrible, oprichnina - 6000-strong oprichniks clad in black, with the skull of a dog and a broom as regalia -, ready to butcher all ranks, even boyars, or the metropolitan himself.

In addition, enslavement was encouraged by the enormous territory land to till - and the sparse population. Mystical crises and huge rebellions pervade Russia's history. The impression is that often religion was used by those in power as ideology and, thus, deviated from its principles.

It would be very hard to negate the intermingling of ancient tendencies with the new ones. How is it possible for the Russians to persist in limbo, between democracy and dictatorship?

As we know, perestroika meant the "reconstruction" after the "break of consciousness" (perelom soznania) and "stunning shock" (sil'neishii shock) (Yurchak 2005: 2), so that the communist system might not crumble. The policies of perestroika were heralded by glasnost' ("openness, public discussion"). Yurchak described a "binary socialism" (Yurchak, 2005: 4) within, although Soviet citizens were portrayed as deprived of agency because of the censored (podtsenzurnaia) culture that was kept away from unofficial publications (samizdat) and from foreign forbidden publications (tamizdat) (Yurchak, 2005: 6).

Brezhnev's rule was associated with stagnation (zastoi). Nevertheless, even in the harshest times of communist rule the subjects experienced Claude Lefort's paradox: the split between the ideological enunciation and the ideological rule. Saint-Simon, political theorist and artist with avant-garde views, had anticipated this paradox when back in 1825 wrote that society could be liberated with the help of a political and aesthetic avant-garde able to fulfil a priestly function (Yurchak, 2005: 11). Socialists were frustrated 
pseudo-priests who never ceased to dream of an ideological church. That is why Saint-Simon envisaged the unity of arts and politics under "a common drive and a general idea" (Egbert, 1967: 43). The purpose was positivistic and propagandistic, not to mention a pinch of totalitarianism. All totalitarian states paid great attention to discourses and to their social realization. For instance, in USSR "the metadiscourse on ideology disappeared from public circulation" (Yurchak, 2005: 7). Analyses were not welcome or they were carefully whitewashed. In an ideologized society, citizens live the effects of the current ideology, but cannot debate on that ideology.

In recognition of the importance of culture in the mechanism of systemic propaganda, as late as 1984 a collective of theoreticians of culture from Moscow's Institute of Marxism-Leninism (Arnol'dov et alii) published the book Marxist-Leninist Theory of Culture (Marksistko-leninskaia teoriia Kul'tury) (Yurchak, 2005: 7). The ideal type of discourse remained what Bakhtin (himself persecuted by the Bolsheviks) termed "authoritative discourse" (avtoritetnoe slovo). Culture was to be surveyed in terms of not only dissemination, but also right in its laboratory of creation (Yurchak, 2005: 9).

Has it been different in terms of agency for the Balkan states?

\section{Serbia before \& now}

South-Eastern Europe has always persisted as an area of transition, as a buffer between West and East. Many Balkan states are, as we know, quite young. Therefore, it is normal for them to have transferred their nationalistic cargo to objects or popular creations.

Ivo Zanić dwelled on "South Slavness" or "Yugoslavism" (Zanić in Resic\& Tornquist-Plewa, 2002: 47). He showed that gusle and šajkača - the cap used by the peasants in Šumadja region -, were chosen as symbols of Serbian belonging, whereas a musical instrument like tamburica and the round black hat traditionally sported by the peasants of Sestine, in the proximity of Zagreb, were the Croatian correspondents.

The signs of power and dynasty-founding myths in this region were displayed and built like in every other part of the world. For instance, the Serbian Karadjordjevic family was propelled into a national dynasty, in spite of the fact that Alexander's great-grandfather, Karadjordje Petrovic, the leader of the Serbian riot of 1804, had been a peasant and a pig trader (Zanić in Sanimir \& Tornquist-Plewa, 2002: 51). This is a testimony of predemocratic access to power. It indicates also that whoever was anointed king conjured all the divine attributes conferred to kingship. It looks like smaller and younger states resort more often to the paraphernalia of national identity than more massive and stable nations. That is why they highlighted it both during the internationalist interval and during the globalist one. 
In Titostalgia. A Study of Nostagia for Josip Broz, 2008, Mitja Velikonja traced the commercialization of Tito's image, which is displayed on almost every touristic object or artefact: not only in Serbia, but across whole ex-Yugoslavia. Some take this "neo-Titoism" seriously, while others frequent it only as "an end-of-the-week pastime" (Velikonja, 2008: 10). The "titostalgia" is a strange phenomenon in the former socialist countries of Yugoslavia and it necessitates a "titology" (Velikonja, 2008: 11), that is an unfathomed research as it were. Are these "eulogies", not to say "hagiographies", displayed in a mass-cultural production a "life after death" or a "life after life" for Broz?, quizzes Velikonja (Velikonja, 2008: 1).

Tito had a life-long success with all manner of artists - "Josip Broz dobar skroz" ("Josip Broz good from top to bottom"), as it reads the slogan imprinted on T-shirts sold across the former federation (Velikonja, 2008: 13). "Titostalgia is part of Yugonostalgia: a lament for Yuga, as it is affectionately called [...] also a lament for Drug Titot (Comrade Tito)" (Velikonja, 2008: 13). There exists also a Leksikon Yu mitologije (A Lexicon of Yu-mythology) edited by Iris Andrić, Vladimir Arsentijević, and Đorđe Matić (2004).

In his own country, Tito was also, even if surreptitiously, surnamed the Balkan Pot-Pot or Stalin's best student (Velikonja, 2008: 14). In contrast, some foreign commentators dubbed him the only true Yugoslav, the last of the Habsburgs (having striven to federalize diverse nations), the communist Luther, the Balkan Caesar, or, simply, a new Henry VIII (Velikonja, 2008: 14). One thing is sure: Tito was not a trite politician. In spite of having broken with Stalin in 1948, some historians saw him as "more of a Stalinist than Stalin" (Barnett, 2006: 82) or as a leader who mounted a "Stalinist resistance to Stalin" (Pavlowitch, 2006: 57-59).

Velikonja noticed that Broz reverberated also as media star, with the mention that he moved in post-communism to the back pages of newspapers, in the rubrics dedicated to tourism, reports, serialized stories, and advertisements (Velikonja, 2008: 17). The researcher identified in this case a depoliticization symptom (Velikonja, 2008: 19). Broz's reappearance is detached (really?) from his communist past. For instance, a company sells bottled water named Tito izvor (Tito Spring). There are still citizens who dress their children as Tito's pioneers (a uniform consisting of a red scarf and a blue cap called Titovka) (Velikonja, 2008: 21).

Consequently, Velikonja cannot but ask himself "Has Broz been 'reborn', or has he actually never left for good but only temporarily withdrawn from mass culture, advertising, folk imagination and minds?" (Velikonja, 2008: 22). Of course, he could extend the same question in relation to communist symbols stencilled on the walls of Università L'Orientale of Naples or to the Marxist posters spread in almost all 
Occidental universities (for instance, University of Lund, where I had the pleasure to meet again Mitja Velikonja).

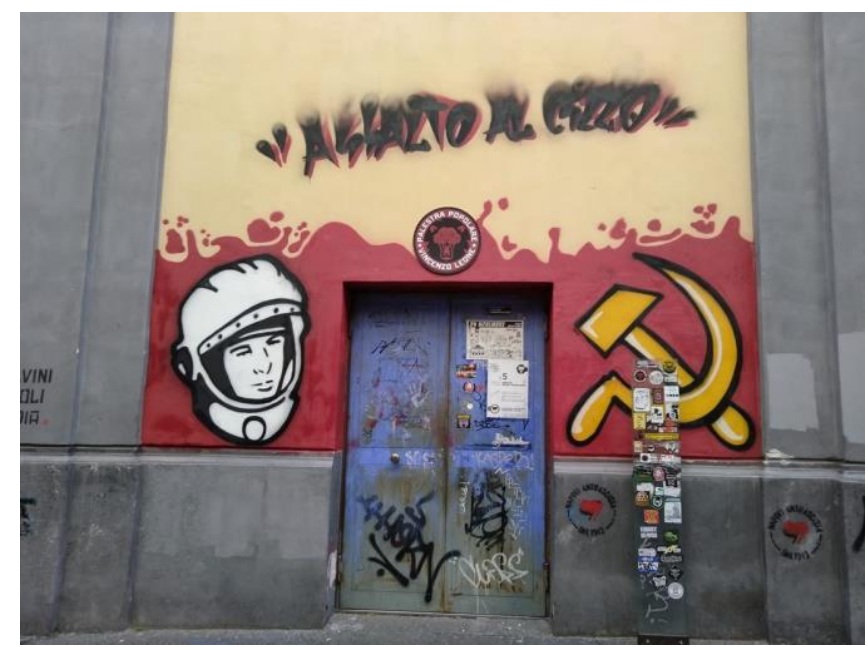

(I. Università L'Orientale of Naples)

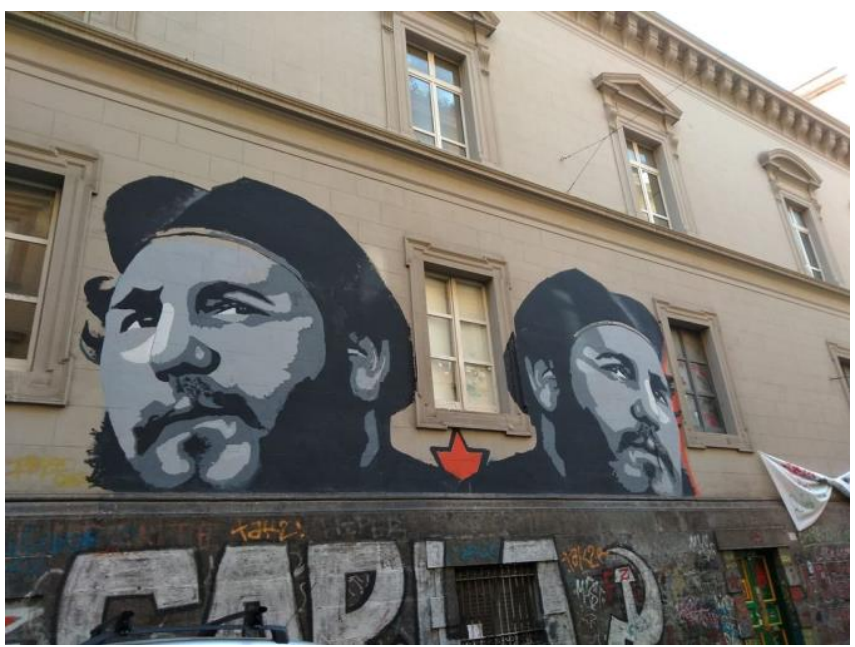

(II. Università L'Orientale of Naples)

This tittooage (Velikonja, 2008: 22) encouraged by Slovenes' predilection for the "father of the nation" is accountable for the fact that in Ljubljana one cannot buy T-shirts imprinted with the image of Anton Korošec, an eminent Slovenian politician in the interwar period, for a comparison, whereas plenty of souvenirs evoking the communist period are on display (Velikonja, 2008: 23).

This phenomenon is not limited to Slovenia or Serbia. Not even in other ex-Yugoslavian countries, one can find representations of mythical or prominent personages of the pre-communist period. Tito, however, is still in 
full bloom. In Croatia, one can buy Brozovo vino (Broz wine) or Tito borovničevec (Tito Bilberry Brandy). In Serbia, it is easy to spot graffiti about Tito (Velikonja, 2008: 23). A historian, Božo Repe, held a lecture in Nova Gorica in May 2008 in which he proclaimed Naš Tito je naš (Our Tito is ours). (Repe in Velikonja, 2008: 23).

The recrudescence of communist points of view may be the consequence of mediated knowledge about a tormented past, even if it is a recent one. However, unmediated memories may be distorted by the hardships of the present. Maurice Halbwach remarked that memory may be "an image entangled among other images, a generic image taken back into the past". Thus, theorists speak of a "politics of memory" backed up by an "industry of memory" (monuments, ceremonies, memorabilia, "official" historiography (Halbwachs, 2001: 75, 78).

Velikonja practises the distinction between testimony and remembering. While the former would build on a "grain of truth", the latter would tend to adjust in accordance with "presentist imperatives" (Velikonja, 2008: 26). Another distinction concerns personal and collective memories. The collective memory is copiously canonized and institutionalized.

There are many faces of nostalgia. Columnist Herb Caen perceived it as a "memory with the pain removed" (Caen in Velikonja, 2008: 27). Other authors surnamed it a "romance with an unhappy ending", "a sad love", or "a retrospective utopia" (Velikonja, 2008: 27), having an antithetic nature.

Velikonja identified four sub-types of nostalgia. There would be a personal and a collective nostalgia. Then, there is a "materialized" nostalgia (for instance souvenirs) and nostalgia as feeling or idea (Velikonja, 2008: 29).

\section{Conclusion}

The purpose of this study was not to pinpoint and discuss the possible resurrection of communism in those countries which were most haunted by this ideological nightmare, but to identify some instances of performative discourse turned into constative ones. Three decades after the fall of communism in Europe, dissimulation in the public discourse is not as imperious as in the $50 \mathrm{~s}$, but the performativity and citationality of communist paraphernalia survived especially in a commercial or nostalgic version. Societies are no longer an enormous theatre, but the seeds of future ideological shows could push up ears to burgeon anytime. The fertilizer of such an ideological theatricality could be exactly the spearhead of capitalism: the win-or-lose neoliberalism. It seems that an unwritten historic law distributes extremist positions in a rotational sequel. The interludes are the revolutions - with their cortege of cruelties, confusions, enthusiasms, and profiteers. 


\section{References:}

Abaza, M. (2006). Changing Consumer Cultures of Modern Egypt: Cairo's Urban Reshaping. Leiden and Boston: Brill. https: //doi.org/10.1017/s0020743808090363

Abercrombie, N. \& Longhurst, B. (1998). Audiences. A Sociological Theory of Performance and Imagination. London: SAGE Publications,. https: //doi.org/10.4135/9781446222331

Acton, E. (1986) Russia (The Present and the Past). New York: Longman. https: //doi.org/10.1086/ahr/92.5.1237

Barnett, N. (2006). Tito (Life \& Times). London: Haus Publishing London.

Bălănescu, F. (2020). Bălănescu Flori în dialog cu Cristian Troncotă. Securitatea noastră cea de toate zilelel Flori Bălănescu's dialogue with Cristian Troncotă. Our Everyday Securitate. Bucureşti: Corint Press,.

Derrida, J. (1977). Of Grammatology. Baltimore: John Hopkins Edition.

Egbert, D. (1 December 1967). "The Idea of "Avant-garde"". In Art and Politics, "The American Historical Review", Volume 73, Issue 2. Oxford: Oxford University Press.

Halbwachs, M. (2001). On Collective Memory. Minnesota: University of Minnesota Press.

Pavlowitch, S. (2006). Tito: Yugoslavia's Great Dictator: A Reassesment. London: C. Hurst \& Co (Publishers) Ltd.

Perrini, M. (1992). "La difficile uscita dal communism dei paesi dell'est Europa"/ "The difficult exit from communism of the south-eastern countries". In Giornale di Brescia, 5-6 febbraio, 1.

Sanimir, R., Tornquist-Plewa B. (Eds.). (2002). The Balkans in Focus. Cultural Boundaries in Europe. Lund: Nordic Academic Press.

Sampson, S. (2002). "Weak States, Uncivil Societies and Thousands of NGOs. Benevolent Colonialism in the Balkans". In Sanimir, R. \& B. TornquistPlewa (Eds.) (2002). The Balkans in Focus. Cultural Boundaries in Europe. Lund: Nordic Academic Press. 27-44.

Velikonja, M. (2008). Titostalgia. A Study of Nostagia for Josip Broz. Ljubljana: Mirovni Institut.

Voloshinov, V. N.2 Michail M. Bachtin (1986). Marxism and the Philosophy of Language. USA: Harvard University Press.

Wedeen, L. (1999). Ambiguities of Domination. Politics, Rhetoric, and Symbols in Contemporary Syria. USA: University Of Chicago Press. https: //doi.org/10.2307/2586277

Yurchak, A. (2005). Everything Was Forever, until It Was no More. The Last Soviet Generation. USA: Princeton University Press.

Zanić, I. (2002). "South Slav Traditional Culture as a Means to Political Legitimization". In Sanimir, R. \& B. Tornquist-Plewa (Eds.) (2002). The Balkans in Focus. Cultural Boundaries in Europe. Lund: Nordic Academic Press, 45-58. 


\section{Links:}

Manifesto of the Communist Party, Marxists Internet Archive (marxists.org) 1987, 3. In https: //www.google.ro/url?sa=t\&rct=j\&q=\&esrc=s\&source=web\&cd=10 \&cad=rja\&uact $=8 \& v e d=2$ ahUKEwillOay MTmAhVIs4sKHSR7Cs8QFjA JegQIAxAC\&url=https\%3A\%2F\%2Fwww.marxists.org\%2Farchive\%2Fma rx\%2Fworks\%2Fdownload\%2Fpdf\%2FManifesto.pdf\&usg=AOvVaw1cOo PQZtsWyBhlodCPbFZx, accessed November 12, 2019, 19: 52.

The Communist Party members in front of the old prison at Piteşti. In https: //adevarul.ro/locale/pitesti/imagini-revoltatoare-tineri-steaguri-comunistefatafostei-inchisori-pitesti-locul-jegurile-anticomuniste-auprimit-pedeapsameritata-foto-1_5d83422c892c0bb0c6bdabf3/index.html, accessed January 12, 2021, 23: 15 .

Young Romanian historians about communist atrocities. In https://www. observatorcultural.ro/articol/istoricul-mihai-demetriade-despre-fenomenulpitesti-si-dispute-institutionale-in-iiccmer-si-cnsas/, accessed January 12, 2021, 23: 20.

Young Romanian historians about communist atrocities. In https://www.Digi24. ro/stiri/actualitate/scandal-urias-intre-cnsas-si-cercetatorii-madalin-hodor-simihai-demetriade-din-cauza-experimentului-pitesti-1209640, accessed January 12, 2021, 23: 25. 